\title{
BATTAL GAZİ DESTANI'NDA GÖNDERGELER VE ANIŞTIRMALAR ÜZERİNE BİR DEĞERLENDİRME
}

\author{
Mehmet Emin BARS*
}

\begin{abstract}
$\ddot{\mathbf{O z}}$
Folklor ürünlerinin en zengin türlerinden biri de destandır. Destanlar, çok uzun bir yaratım ve gelişim süreci sonunda günümüze kadar ulaşmışlardır. Destanlarda tarihî unsurların yanında milletlerin âdet, gelenek, görenek ve yaşayış tarzları ile ilgili başka kaynaklarda bulunmayan bilgiler de yer alır. $\mathrm{Bu}$ tür eserler yazı dilinin de önemli belgeleridir. Türk edebiyatının en çok tanınan ve bilinen destanlarından biri de Battal Gazi Destanı'dır. Destan hakkında yurt içinde ve dıșında kitaplar ve makaleler yazılmıș, adına bilgi şölenleri düzenlenmiştir. Battal Gazi Destanı Anadolu'nun sınır bölgelerinde Müslümanların Bizanslılarla yaptıkları savaşlar neticesinde doğmuştur. Destandaki kişiler iki farklı ideolojinin temsilcileri durumundadırlar. Çalışmamızda Battal Gazi Destanı’nda gönderge ve anıştırmalar incelenmiştir. İnceleme sonucunda gönderge ve anıştırmaların anlatının oluştuğu sosyal, kültürel, dinî çevre hakkında önemli bilgiler verdiği görülmüştür.
\end{abstract}

Anahtar Sözcükler: Battal Gazi, destan, gönderge, anıştırma.

\section{AN ASSESSMENT OF THE ALLUSIONS AND REFERENCES IN BATTAL GAZI EPIC}

\begin{abstract}
One of the richest kind of folkore are also epic. Epics at the end of a very long creation and development process has come up to the present. In addition to the historical elements in epics the information related with the tradition, costoms and life styles of the nations not found in any other sources is located. This kind of works is also important document of the written language. One of the most well-known and known epics of Turkish literature is the epic of Battal Gazi, too. The boks and articles were written about the epic in the country and abroad and symposiums were organized in the name of the epic. The Epic of Battal Gazi was born as a result of the wars between Muslims and Byzantines in the border regions of Anatolia. People in the epic are the representatives of two different ideologies. In our studies, the allusions and references in Battal Gazi Epic were examined. With the examination results, it was observed that the references and the allusions give information about the religious, cultural and social environment in which the narration was formed.
\end{abstract}

Keywords: Battal Gazi, epic, reference, allusion.

*Dr.; Pasinler Ortaokulu, Erzurum, m_e_bars_21@ @otmail.com. 
"Yeniliği ne olursa olsun, öyleyse bir metin alıntı, alıntıların bir karışımıdır.”

Jean Claude Vareille

\section{Giriş}

Milletler için destan, efsane, menkıbe gibi edebî mahsullerin önemi büyüktür. Bu mahsuller bir milletin ruhunda yaşayan belgelerdir. Edebî ürünlerin bir kısmında tarih ile menkıbe birbirine karışmışır. Destanlar, çok uzun bir yaratım ve gelişim sürecinin tamamlanması sonucunda günümüze kadar ulaşmışlardır. Milletlerin karakterini göstermeleri açısından, destanların en büyük özelliği ferdî olmamalarıdır. Halk anlatmalarının içinde yaratıldıkları topluma mal olabilmeleri için, uzun bir oluşum sürecinden sonra, yüzyıllar boyu sürecek olan nesilden nesile aktarılma yoluyla, günümüze kadar gelmişlerdir. Tarihî unsurların yanında milletlerin geçmişteki belki de hiçbir kaynakta bulunmayan bilgileri destanlarda yer almaktadır.

Türkler Anadolu'yu vatan yaptıktan sonra bu coğrafyada üç tane önemli destan vücuda getirmişlerdir: Battal Gazi Destanı, Dânişmend Gazi Destanı ve Saltuk Gazi Destanı. Anadolu'da teşekkül etmiş ilk Türk destanı Battal Gazi Destanı'dır. Battal Gazi Destanı, muhtemelen XI - XIII. yüzyıllar arasında teşekkül etmiş; XIII. yüzyılda kaleme alınmıştır. İlk şeklinin mensur olduğu bilinmektedir. "Battalnâmenin Türkiye dışında Azerbaycan, Kazakistan, Tataristan, Kırgızistan ve Özbekistan'da tespit e[dilen], Anadolu Türkçesinin yanında farklı lehçelerle meydana getirilmiş metinlerini ihtiva eden çok sayıda nüshasının bulunması menkıbelerin yaygınlığg konusunda somut neticeler ortaya koymaktadır” (Cicioğlu, 2013: 428 429). Destanın dili sadedir, içerisinde geçen Arapça ve Farsça kelimeler Türkçe konuşan insanların yabancı olmadığı kelimelerdir. Battal Gazi Destanı'nın Anadolu ve Balkanlarda Türkçe konuşan hemen herkes tarafından tarih boyunca bilinmesi, sevilmesi, okunması ve yaygınlaşması dilinin sadeliğinden kaynaklanıyor olmalıdır. Battal Gazi Destanı'nı Anadolu serhatlerindeki daimî Türk - Bizans mücadeleleri doğurmuştur. Bizanslıların Akrit ve Apelatlarına karşı Müslüman Türklerin alpları ve gazileri vardı. Battal Gazi Malatya'da doğmuş, Abbasilerden Mutasım ile Vâsık Billâh zamanlarında yaşamıştır. Battal Gazi peygamber sülalesinden gelen tarihî bir Arap cengâveri değil, Anadolu serhatlerinde İslamiyet mefkûresi için çarpışan Türk gazilerinden biridir (Köprülü, 2004: 277 - 278). Battal Gazi Destanı Türk muhayyilesiyle şekillenen millî destanlarımız arasında yer almaktadır.

Battal Gazi Destanı'nda Müslümanların Bizanslılara ve diğer gayrimüslimlere karşı verdiği mücadeleler temsilî olarak anlatılır. 
...Battal Gazi Destanı Anadolu'nun sınır bölgelerinde Müslümanların Bizanslılarla yaptıkları savaşlar neticesinde doğmuştur. Buradan yola çıkarak Battalnamelerin tarihsel ve destansı kahramanı Battal Gazi (Cafer)'nin Anadolu'nun fethinde destanlaşmış gazilerden biri olduğu söylenebilir. Battal Gazi, inancını yaymak için savaşan bir kahramandır. Soyca Hz. Muhammed'e bağlanarak kendisine Seyyid unvanı da verilmiş ve böylece yenilmez bir kahraman haline gelmiştir. İslâm dini uğruna savaşması destana ideolojik bir kimlik kazandırmaktadır, çünkü Battal'ın tek hedefi inancının bütün insanlar tarafindan kabul edilmesidir. Onun bu kişiliği ve mücadeleleri destan anlatıcısı tarafından önce sözlü anlatım geleneği içinde ve daha sonra yazılı eserlerle belgelenerek destanlaştırılmıştır (Arak, 2010: 39).

Battal Gazi Destanı'nda iki dünya görüşünün çarpışması görülmektedir. Bağdat'taki Halife ile Bizans Kayseri iki ayrı dünya görüşünün gücünü simgelemektedirler ve destanda onların arasında geçen mücadeleler ortaya konmaktadır. Destanda yer alan kişiler bu iki ideolojinin temsilcileri durumundadırlar. Destan kişileri hem tarihsel hem de destansı nitelikler taşırlar. Bu nedenle Battal Gazi'nin tarihsel kaynaklarda bulunan kişiliği ile destandaki kişiliği birbirinden farklıdır. Destanda geçen olaylar, oluşumundan yazıldığı zamana kadar, halk tarafından bir takım değişikliklere uğratılmıştır.

Bir destanın kaynağını ilişkili olduğu ulusun kendi tarihi oluşturur. Ulusların idealleri bir kahramanda simgeleştirilerek halk kitleleri etkilenmeye çalışılır. Battal destanda yaptığı mücadelelerle bütün Müslüman topluluklar için örnek oluşturmaktadır. Destanların görevi tarihsel olayları sıralamak olmadığı için, anlatıc1, ulusun kahramanda görmek istediği özellikleri kendisi destana ekler (Arak, 2006: 53).

Destanlar, tarihsel olayların gerçek yönüyle ilgilenmemektedirler. Olayları destansı özelliklere uygun olarak işleyen eserlerdir. Battal Gazi Destanı da Müslümanlar ve Hristiyanlar arasında geçen olayların yer ve zaman gösterilerek incelenmesi değil, bu olayların halk edebiyatına yansıyış biçimidir.

Makalemizde Battal Gazi Destanı'nda kullanılan gönderge ve anıştırmalar incelenmiştir. Destandaki gönderge ve anıştırmaların tespiti anlatının oluşturulduğu tarihî, sosyal ve kültürel zemin ile ilgili bilgiler verecektir. İncelememizde, Nezif isimli bir şahıs tarafından yazılan ve Hasan Köksal ${ }^{1}$ tarafindan sadeleştirilerek günümüz Türkçesine aktarılan

\footnotetext{
${ }^{1}$ Hasan Köksal tarafindan Atatürk Üniversitesi Fen - Edebiyat Fakültesi Türk Dili ve Edebiyatı Bölümünde 1983 yılında Battalnâmelerde Tip ve Motif Yapısı adlı doktora tezi hazırlanmıştır. Köksal, çalışmasında incelememizde kullandığımız yazma metni kullanmıştır. Tez; giriş, iki ana bölüm ve bibliyografyadan meydana gelmektedir. Giriş bölümünde epik tür hakkında genel bilgi, Türk - İslam toplumunda epik türle birlikte gelişen insan tipleri tanıtılmıştır. Birinci bölümde Battalnâmedeki tipler, ikinci bölümde ise Battalnâmedeki motifler üzerinde durulmuştur (Köksal,
} 
Hicri 1206 tarihli yazma metin (Köksal, 2007) kullanılmıştır. Battal Gazi Destanı’nın olay örgüsü kısaca şu şekildedir:

1. Resulullah'a Cebrail tarafından 200 yıl sonra Malatya'dan Cafer adlı bir yiğidin çıkıp Rum'u alacağı haberi verilir. Sahabelerden Abdülvahab da bunu görecektir. Resulullah, Cafer'e ulaştırması için Abdülvahab'a bir mektup verir.

2. Hz. Ali’nin soyundan gelen Ali el Medeni, Yezidiler zamanında önce Bağdat'a oradan da Malatya'ya yerleşir. Torunlarından Hüseyin Gazi Malatya seraskeri olur.

3. Hüseyin Gazi bir gün bir geyiği avlamaya çalışırken bir mağaraya rastlar. Mağarada bir at ve üzerinde bir bohça bulur. Hüseyin Gazi'nin Cafer adlı bir oğlu olur.

4. Hüseyin Gazi, Mamuriye şehrinin beyi Mihriyayil’in adamları tarafından öldürülür. Hüseyin Gazi'nin yerine Abdüsselam serasker olur.

5. Cafer 13 yaşına gelir. Babasının mansıbını Malatya beyinden ister. Cafer, babasını öldüren Mihriyayil’i öldürür. Babasının intikamını alır.

6. Abdülvahab, Resullullah'ın mektubunu Cafer'e verir. Cafer, babasının mansıbını alarak serasker olur.

7. Cafer, Ahmer adlı bir kâfiri yener, Ahmer Müslüman olur. Ahmer tarafindan Cafer'e Battal ismi verilir.

8. Battal, önce amcasının kızı Zeynep Hatun'la daha sonra Rum Kayseri'nin kızı Mahpiruz ve Taryun'un kızı Gülendam ile evlenir.

9. Battal'a çok kere hile ile kötülük yapmaya çalışan Abdüsselam, Kayser'e esir düşer. Battal, Abdüsselam'ı kurtarır.

10. Battal, Malatya şehrinin etrafındaki tüm beyleri yenerek Malatya emirine bağlar.

11. Birçok defa Kayser tarafından zindana atılan Battal, her seferinde kurtulmayı başarır.

12. Emir Ömer'in kızını isteyen Battal'dan çok mal istenir. Battal, bu malları elde etmek için Hindistan'a gider.

13. Battal, devlerle, cadılarla çeşitli mücadelelere girişir. Kaf Dağı'na gider, padişahın kızını kurtarır. Her seferinde Hızır ile perilerin yardımını alır.

1984). Tez, 1984 yılında Kültür ve Turizm Bakanlığı tarafından kitap olarak yayımlanmıştır. Çalışma, Battalnâmeler üzerinde geniş kapsamlı ilk bilimsel çalışmalardan biri olması bakımından önemlidir. 
14. Battal, Emir Ömer’in istediği malları alır. Kayser tarafından yağmalanan Malatya, Battal tarafından kurtarılır. Battal'ın getirdiği mallarla şehir yeniden imar edilir.

15. Peygamberlik iddiasında bulunan Babek ile halifelik iddiasında bulunan Hakem, Battal tarafindan öldürülür.

16. Battal'1 gören Kayser'in kızı ona âşık olur. Düşman saldırısından Battal'ı uyandırmak için kız tarafından atılan küçük bir taş Battal'ın ölümüne neden olur (Köksal, 2007).

\section{Battal Gazi Destanı'nda Göndergeler}

İki tip metinlerarası ilişkiden söz etmek mümkündür. "İki ya da daha çok metin arasında kurulan 'ortak birliktelik ilişkisine dayanan metinlerarası ilişkiler; 'türev ilişkisine dayanan metinlerarası ilişkiler" (Aktulum, 2007: 93). Alıntı - gönderge, gizli alıntı ve anıştırma ortakbirliktelik ilişkisine; yansılama, alaycı dönüştürüm ve öykünme ise türev ilişkisine dayanan metinlerarası biçimler olarak kabul edilir. Metinlerarası yöntemler açık ve kapalı olmak üzere iki biçimde ortaya çıkar. Açık ilişkilerde bir metne yapılan gönderge, yapıtın adı ya da yazarı ve alıntılanan kesitler açıkça belirtilirken; kapalı ilişkilerde bir yapıta ayrışık unsurlara yer verildiği konusunda hiçbir ipucu verilmez. Bu anlamda alıntı - gönderge açık, gizli alıntı ve anıştırma da kapalı metinlerarası ilişkilerdir.

Metinlerarası ilişkinin en belirtgesel biçimi alıntıdır. Alıntı, bir metnin başka bir metindeki varlığını somut biçimde görünür kılar. Alıntı, bir görüşü açıklamak, desteklemek için bir yazardan alınan parçadır. Alıntı bir sözce başka bir bağlamda yinelenir, böylece iki ya da daha çok metin arasında bir alışveriş sağlanır. Alıntı bilinçli yapılan bir anımsamadır. Başka bir metne ait kesit yeni bir metne sokularak yeni bir anlam yüklenir. Alıntı açıkça belirtilir. Yazar ayraçlar veya italik yazı ile söylemin ya da sözcenin kendisine ait olmadığını açıkça bildirir. Ayraçlara ya da italik yazıya başvurmadan alıntı yapmak, onu kendisine mal etmek anlamına gelir. Bir yazar yeni bir metin oluştururken başka metinlerden aldığı parçaları bir bütün oluşturacak biçimde yan yana kaynaştırır, yeni bir metin oluşturur. O hâlde her yazı bir alıntı ve yeniden yorumlamadır. Bir sözcenin bir metinden ötekine geçişi iki metin arasında bir köprü kurar. Bakhtin'in söyleşim, Compagnon'un ilişki dediği şeydir. İki dizge arasındaki ilişkiyi yazar kurarken okurdan bunu saptamak ve anlamsal işlevlerini çıkarması beklenir. Çoğu zaman bir metinde açık bir biçimde yer alan alıntı; okurundan özel bir kavrayış, bilgi birikimi gerektirmeden kendini belli eder. Alıntı açık olduğundan kavranması, saptanması kolaydır. Ancak alıntının tanımlanması ve yorumlanmasında dikkat etmek gerekir. Alıntılara çok yer veren bir metin çoğu zaman bir mozaiğe, kolaja benzer (Aktulum, 2007: 94-99). 
Gönderge ise bir yapıtın başlığını ya da bir yazarın adını anmakla yapılır. Göndergede bir metinden alıntı yapılmadan okur başka bir metne gönderilir.

Geniş anlamıyla bir metinde bir çağın, bir türün (yazınsal olsun ya da olmasın), bir geleneğin $v b$. yanmetinsel göstergelerden biriyle olduğu kadar yalnızca yapıt başlıklarının, yazar adlarının ya da roman, trajedi, şiir kişisinin, tarihî bir kahramanın, kutsal kitaplardan birinin adının açıkça anılması alıntısız göndergeleri işin içerisine sokar (Aktulum, 2011: 435 - 436).

Örneğin, Julien Gracq'ın Un Beau Tenebreux adlı romanı Hz. İsa'ya, Napolyon'a, romantik kahramanlara, Atala'ya, Vigny’ye ve daha pek çok roman kişisine, yapıta, yazara açık ya da kapalı göndermede bulunur. Göndergeye yapıtın bağlamına göre belli bir anlam yüklediğinden çoğu zaman anıştırma ile karıştırılır (Aktulum, 2007: 102).

Battal Gazi Destanı'nda da göndergeler kişi adlarının anılmasıyla gerçekleştirilmiştir. Herhangi bir metinden açık alıntı yapılmamış, tarihî, dinî kişiler, anlatı kahramanları, mitolojik varlıklar adları anılarak metin içerisine sokulmuşlardır. Bu göndergeler bulundukları yeni metinde anlamsal dönüşümlerle yeni bir anlatının oluşumuna katkıda bulunmuşlardır. Destanda yapılan göndergeleri şu başlıklar altında incelemek mümkündür:

\subsection{Melekler}

a. Cebrail: Hz. Peygamber'in gönlü Rum'a meyledince Cebrail-i Emin, Allah'tan haber getirir. Cebrail, peygamberlikten 200 yıl sonra Malatya'da Cafer adlı bir yiğidin doğacağı, kiliseleri yıkıp yerine mescitler ve medreseler yapacağı, İstanbul'un kapılarını açacağı haberini getirir (Köksal, 2007: 14)2. Anlatıda Cebrail, Allah ile Peygamber'i arasında haberleşmeyi sağlar. Gerçekte de Cebrail'in görevi Allah ile peygamberler arasında elçilik etmektir. Cebrail, Allah'ın emirlerini tebliğle görevli bir melektir. Hz. Muhammed'e Hira Dağı'nda Allah'ın “oku” emrini de o getirmiştir. Cebrail ayrıca edebiyatta "Mirac'da peygamberimizi Arş’a dek götürmesi, kanatlarıyla uçması, Sidre'de makam edinmesi, vahiy getirmesi, Hz. İbrahim'e ateşe atılacağı zaman yardım teklif etmesi, Meryem'i nefesiyle gebe bırakması ve Cennet varlığ oluşu” (Pala, 1995: 106) gibi özellikleriyle anılır.

b. İsrafil: Anlatıda Seyyit Battal Gazi’nin savaş meydanlarında attı̆ğ naradan sıkça bahsedilir. Seyyit öyle bir nara atar ki düşman askerlerinin içine korku düşer: Bu nara düşman ordusunda Hz. İsrafil'in kıyamet gününde üfleyeceği sûra benzetilir: "Kuşluk vaktinde Seyyit bir tepeye çıkıp gök gürültüsünü andıran bir nara çekti. Sandılar ki kıyamet koptu veya Hz. İsrafil'in kıyamette üfleyeceği sûr sesidir" (114). İsrafil, dört büyük melekten biridir. Kıyamet

\footnotetext{
${ }^{2}$ Alıntılar aynı eserden yapıldığından bundan sonra sadece sayfa numaraları verilecektir. 
Günü’nü, haşır ve neşri üfleyeceği suruyla bütün varlıklara haber verecektir. İslam inancina göre suru ilk üfürüşünde tüm canlılar ölecek, ikincisinde hesap için dirileceklerdir. İnsanlar, o gün dünyada yaptıklarının hesabını vereceklerinden içlerinde büyük korku taşıyacaklardır. Herkes kendi derdine düşecek, en yakınlar bile birbirlerinden kaçacaktır. Battal Gazi’nin narasından duyulan korku Kıyamet Günü'nde duyulan korkuya benzetilir. İsrail'in diğer bir görevi de Levh-i Mahfuz'da yazılanları diğer meleklere bildirmektir. Levh-i Mahfuz, Allah'ın kudretiyle olacak şeylerin yazılı olduğu levhadır (Pala, 1995: 290).

\subsection{Peygamberler}

a. Hz. Muhammed: Anlatıda en fazla adı anılan ve göndergede bulunulan kişi Hz. Muhammed'dir. Anlatının başından sonuna kadar Seyyit'in yaptığı tüm işlerde onun adı görülmektedir. Seyyit'e ve İslam ordusundaki yiğitlere düşlerinde görünmek suretiyle yol gösterir. Anlatıda yapılan tüm mücadeleler onun anlattığı dinî öğretileri diğer insanlara yayma, toprakları İslam toprağı hâline getirme uğrunadır. Anlatının görülen kahramanı Seyyit olmasına rağmen, tüm olayların perde arkasında gerçek kahraman hüviyetiyle Hz. Peygamber bulunmaktadır. Daha anlatının başında Seyyit'in ne zaman geleceği ve İslam adına neleri yapacağının haberi kendisine verilir. $\mathrm{O}$ da sahabelerinden birini iki yüz yıl sonrası için ona yardımcı olarak gönderir. Anlatıda özellikle rüyalarda kişilere görünerek, onlara yapacaklarını veya gelecekte olacaklarla ilgili haberler verir. Battal Gazi onun neslinden geldiği için "seyyit" unvanını kullanır. "Ilk peygamber ve ilk insan Hz. Adem'den itibaren evlattan evlada geçen 'son peygamberlik nuru' O’nda sahibini bul[ur]” (Pala, 1995: 397). Birçok şair onun hakkında naatlar yazmış; hayatı, savaşları ve mücadeleleri edebî eserlere konu olmuştur.

b. Hz. Adem: Seyyit Battal'ın babası Hüseyin Gazi bir gün geyik kovalarken mağaraya rast gelir. Mağaradan içeri girer. Burada bir sarı at görür. Atı tutmak ister; ama at çifte atar. Hüseyin Gazi geri çekilir. Mağaranın içinden bir ses duyulur: "Sakin ol! Henüz vakit olmadı ki ben çıkayım. Seni Hak Teâla Cafer'e verdi. O gelecek. Yeryüzünde gazâlar kılacak. Âlemi kara kâfirlerin baskısından kurtaracak. O yiğide teslim ol ve bağlan" (17). At bu sesi işitince yerinde durur. Hüseyin Gazi atı yularından tutar. Atın sırtındaki bohçayı açar. Bohçadan çıkan eşyalardan biri Adem Peygamber'in iki bölük saçıdır. Hz. Adem, semavî dinlere göre Allah'ın yarattığı ilk insan ve peygamberdir. "Ebü'l-beşer" (insanlığın babası) künyesi, "safiyullah" (Allah'ın temiz kulu) sıfatıyla anılır. Hz. Adem'in kıssası birçok kaynakta çeşitli teferruatıyla anlatılmıştır. Edebiyatta da bu kıssadan çokça faydalanılmıştır. Çamurdan yaratılması, meleklerin kendisine secde etmeleri, Ezazil'in secde etmemesi ve şeytan oluşu, yasak meyveye el uzatması, Cennet’ten kovulması gibi konular eserlerde anılmıştır (Efe, 2007: 17 - 29). Anlatıda Hz. Adem'in iki bölük saçından bahsedilir. Saç ve uzun ömür arasında bir bağ 
kurulabilir. Rivayete göre Hz. Adem'e 1000 yıllık bir ömür verilmiş, o da bunun kırk yılını Hz. Davud'a bağışlamıştır.

c. Hz. Davut: Atın sırtındaki bohçada bulunan diğer eşya ise Davut Peygamber'in zırhıdır. Hz. Davut, hem peygamber hem de sultandır. Semavî kitaplardan Zebur ona indirilmiştir. Hz. Davut, sesinin güzelliğiyle bilinir. Zebur'u okuduğu zaman herkes onu hayranlıkla dinlermiş. Bu okuma o kadar etkili olurmuş ki bazıları kendinden geçip ruhunu teslim edermiş. Gür ve kalın sese "davudî” denilmesi bu yüzdendir. Mizmar adlı çalgııı çok güzel çalarmış. Eliyle demir plakalardan zırh yaparak geçimini sağlayan Hz. Davut, devlet hazinesinden para almazmış. Kırk yıllık saltanatından sonra yerine oğlu Süleyman hükümdar olmuştur (Pala, 1995: 133 - 134). Anlatıda Seyyit'e bırakılan zırh, Hz. Davut'un bir hükümdar olmasına rağmen geçimini sağlamak için yaptığı zırhlara bir göndergedir.

ç. Hz. İshak: Anlatıda Davut Peygamber'in zırhının yanı sıra İshak Peygamber'in olduğu söylenilen başka bir zırhtan da bahsedilir. Ancak kaynaklarda zırh ile Hz. İshak arasında herhangi bir ilişkiye tarafımızdan rastlanmamıştır. Hz. İshak, Hz. İbrahim'in ikinci oğludur. Annesi Sara'dır. Filistin civarında ömür süren İshak Peygamber'in soyundan birçok peygamber gelmiştir. Peygamberlik kendisinden sonra oğlu Yakup'a geçmiştir (Pala, 1995: 287).

d. Hz. İsa: Anlatıda Hz. İsa'nın ölüleri dirilttiğine değinilir. Seyyit, Halut ile Calut'u öldürür; kavmini İslam'a davet eder. Kavim, Hz. İsa’nın ölüyü dirilttiğini söyleyerek ondan ölüyü diriltmesini böylece Müslüman olacaklarını söyler (94). Hz. İsa İsrailoğullarının son peygamberidir. Kendisine İncil inmiştir. Bir mucize eseri olarak Meryem'den babasız olarak dünyaya gelmiştir. Meryem sûresinde bu olaylar teferruatlı biçimde anlatılmıştır. Hz. İsa, Cebrail'in Meryem'e üflediği ruhtur. Ölüleri diriltmek, körlerin gözlerini açmak, bebekken konuşmak, çamurdan kuşlar yapıp can vermek, su üstünde yürümek gibi mucizeler göstermiştir. Otuz yaşında peygamber olan Hz. İsa, üç yıl boyunca halkı Allah yoluna çağırmasına rağmen ona sadece on kişi inanmıştır. Bu on kişiye havarî adı verilmiştir (Pala, 1995: 285 - 286). Ölüleri diriltmek Hz. İsa'nın mucizelerinden biri olduğundan bu olaya göndergede bulunulmuştur.

e. Hz. Musa: Halut ile Calut'un kavmi, Müslüman olmaya karar vermeden önde $\mathrm{Hz}$. Musa'nın da birçok mucizesi olduğunu söyler (94). Hz. Musa da diğer peygamberlere verildiği gibi, birçok mucizesiyle edebiyatımızda en çok ismi geçen peygamberlerden biridir. Tur Dağı'nda Allah ile konuşması nedeniyle kendisine "Kelimullah" denilmiştir. Firavun tarafından getirilen tüm sihirbazları asasıyla yenmesi, yine asasıyla Kızıldeniz'i ikiye yarması, elini koynuna soktuğunda bembeyaz bir nura dönüşmesi, Hızır ile birlikte yolculuğu, suları kan şeklinde akıtması gibi birçok mucizesiyle anlatılarda kendisinden bahsedilir (Pala, 1995: 402 403). 
f. Hz. İlyas: Halut ile Calut kavmi, Seyyit’ten ölüyü diriltmesini ister. Seyyit, bu isteği İlyas Peygamber'in duasıyla gerçekleştirir (94). Hz. İlyas da İsrailoğullarına gönderilen peygamberlerden biridir. Kavmini ibadete çağırdığında puta tapan kavmi ondan yüz çevirir. Allah da onların memleketinden bereketi kaldırır. Yağmur yağmaz olur. Açlıktan leşleri yemeye başlayınca Hz. İlyas'ın sözüne inanmaya başlarlar. Ancak ondan sonra tekrar azarlar. Bunun üzerine Hz. İlyas memleketini terk eder; kırlarda, mağaralarda yaşar (Pala, 1995: 280). Bütün peygamberlerin duaları makbuldür. Çünkü onlar Allah'ın seçkin, en sevdiği kullarıdır. İnsanları Allah'ın emir ve yasaklarına uymaya davet eden peygamberler, kavimleri kendilerinden yüz çevirip başlarına bir musibet geldiğinde, onlar için dua etmekten çekinmemişlerdir. Neredeyse tüm peygamberlerin hayatlarında buna benzer örnekler görülür. Hz. İlyas da Allah'ın emirlerine uymayan, kendisinden yüz çeviren kavminin başına gelen açlıkla sınamada onlar için dua etmiş; Allah da duasını kabul ederek musibetini kaldırmıştır (Efe, 2007: 220). Seyyit'in Hz. İlyas'ın duasıyla ölüyü diriltmesi buna bir göndegedir.

g. Hz. Yunus: Seyyit, Mihrasep'in kızını kurtarmak için yola çıktığında bir deniz kenarına gelir. Burayı aşmak için bir gemi gereklidir. Seyyit Allah'a yalvarır. Ansızın bir dalga kopar, arkasından bir balık çıkar. Bu balık bir dağı andırır. Kenara yaklaşır ve güzel konuşmasıyla selam verir: "Ya Seyyit! Ben Yunus Peygamber'i karnımda kırk gün barındıran balığım. Bu sebepledir ki ben bütün balıkların şeyhi unvanını aldım. Bugün bir ses işittim, 'yürü var, Seyyit Battal'ı sudan geçir' deniliyordu. Şimdi gel, benim sırtıma bin, seni öte yakaya geçireyim” (192). Seyyit balığın sırtına biner. Balık, Seyyit’i bir adaya götürür, sonra denizde kaybolur. Seyyit, devi bulur; başını keser; derisini yüzer. Kızı kurtarır. Deniz kıyısına geldiğinde tekrar o balık tarafından karşı kenara götürülür. Bu olayda ise Hz. Yunus'a göndergede bulunulmuştur. Hz. Yunus, İsrailoğulları peygamberlerindendir. Musul dolaylarında bulunan Ninova şehri halkına gönderilir. Halkına Allah'ın azabını haber verdiyse de halkı ona inanmaz. Bunun üzerine Dicle kenarında bir gemiye Allah'ın izni olmadan gizlice biner. Gemiye izinsiz binen Hz. Yunus, gemidekiler tarafından denize atılır; büyük bir balık tarafından yutulur. Hz. Yunus hatasını anlar, balığın karnında Allah'a tövbe eder, Allah da onu affeder. Bunun üzerine balık onu selametle sahile çıkarır (Pala, 1995: 280). Yunus Peygamber'i karnında selametle taşıyan balık, bu kez Seyyit'in başı sıkıştığında onun yardımına koşar. Hz. Yunus, balık karnında iken Allah'a tövbe etmiş, bunun üzerine Allah balığın karnını onun için ferahlık veren bir yer hâline getirmişken; Seyyit de çaresiz kalınca Allah'a Yunus Peygamber misali dua etmiş, Allah onun da duasına icabette bulunmuştur. Yunus Peygamber balığın karnında seyahat ederken, Seyyit balığın sırtında seyahat eder. Ayrıca balık Seyyit ile konuşur, ona yardım etmek için geldiğini anlatır. 
ğ. Hz. Süleyman: Seyyit, oğlunu öldüren cazıyı yakalamak için bir dağın tepesine çıkar. İçi karanlık bir kuyudan aşağı iner. Bir kapı görür, buradan içeri girince bir saraya rastlar. Orta yerde Süleymanvari bir taht görür (253 - 254). Burada Hz. Süleyman'a göndergede bulunulur. Hz. Süleyman, Davut Peygamber'in oğludur. Babasının ölümünden sonra hem hükümdarlık hem de nübüvvetine varis olur. On üç yaşında tahta çıkan Hz. Süleyman kırk yıl kadar saltanat sürer. İsrailoğulları en kudretli dönemlerinden birini onunla yaşar. Emrine hayvanlar, rüzgârlar, cin ve şeytanlar verilir. Hayvanların dilinden anlar; hayvanlardan, cinlerden ve insanlardan oluşan muazzam bir orduya sahip olur. Süleymanvari bir taht ile Hz. Süleyman'a göndergede bulunulmuş, onun güç ve ihtişamı anlatılmıştır.

h. Hz. Yusuf: Anlatıda divan edebiyatında mesnevi türünde, halk edebiyatında ise halk hikâyesi türünde işlenen Yusuf ile Züleyha kıssasına göndergede bulunulur. Seyyit Battal, Emir Ömer ile dolaşmaya çıktığı bir gün bir bağa rastlar. Seyyit Battal burada kasrın penceresinde ayın on dördüne benzeyen bir kız görür. "Onun boynu ve kulağı açık, üzeri mücevherlerle doluydu. Pencereden dışarı çıkmıştı. Binlerce Mısırlı Züleyha'nın Yusuf'u onun yanında şaşkına dönerdi. Hemen ilk bakışta yüz bin kere can-1 gönülden âşı oldu. O da Seyyit’i görüp deliye döndü” (48). Yusuf ile Züleyha hikâyesinin kaynağı Tevrat'tır. Türk, Arap ve İran edebiyatlarında çokça işlenmiştir. Allah tarafından Kur'an-1 Kerim'de kıssaların en güzeli olarak nitelenen Yusuf kıssası, en çok okunup anlatılan hikâyelerden biridir. Konuyu işleyen tüm şairler 111 âyetlik Yusuf sûresini değişmez kaynak olarak kullanmışlardır (Külekçi, 1999: 132 - 137). Yusuf Peygamber, dünyanın en güzel insanı olarak bilinir. Edebiyatta sevgili harikulade güzelliğe sahip olan Yusuf'a benzetilir. Züleyha, Yusuf'a âşık olur; ancak onu bir türlü kandıramaz. Mısırlı kadınlar tarafından aşkı duyulunca onunla alay edilir. Züleyha seçkin kadınları çağırdığı bir davette ellerine bıçak verir, önlerine meyve koyar. Kadınlar Yusuf'un güzelliği karşısında kendilerinden geçip ellerini keserler (Daşdemir, 2012: 259). Züleyha da Mısır'ın en güzel kadınlarından biridir. Hem zengin hem de güzel olan Züleyha birçok kişinin isteyip de ulaşamayacağı bir kadındır. Yusuf kıssasında Züleyha, Yusuf'u elde etmek için elinden geleni yaparken bu durum Battal Gazi Destanı'nda dönüşüme uğrar. Seyyit Battal, Yusuf'a; Zeynep Hatun, Züleyha'ya benzetilmiştir. Ancak bu kez binlerce Yusuf, Züleyha'nın yanında şaşkına dönecektir. Aşs tersine dönmüş; bu kez Yusuf, Züleyha’yı elde etmeye çalışacaktır.

\subsection{Dört Halife}

a. Hz. Ebubekir: Hz. Peygamber bu ölümlü dünyadan göç ettikten sonra “...hilâfet görevi [önce] Ebubekir'e kal[1r]. Ebubekir bu görevi 2 yıl sürdür[ür]...” (15). Hz. Ebubekir, ilk dört halifeden birincisidir. Cennetle müjdelenen on kişinin en üstünü kabul edilir. "Siddîk" 
lakabıyla tanınır. Hz. Peygamber'in peygamberliğinden önce ve sonra onun en yakın dostudur. Kureyş'in önde gelen kişilerinden biridir. İslamiyet'i kabul eden dördüncü kişidir. Hicret esnasında ve tüm savaşlarında Hz. Peygamber'in yanından hiç ayrılmaz. Kur'an-ı Kerim'i ilk defa bir araya getiren odur. Tevazu ve cömertliğiyle dillere destan olur (Pala, 1995: 160 - 161). Hz. Ebubekir 632 - 634 yılları arasında iki yıl süreyle halifelik yapar. Metinde buna göndergede bulunulur.

b. Hz. Ömer: Hz. Ebubekir'in ölümünden sonra halifelik sırası Hz. Ömer'e gelir. Anlatıda Hz. Ömer'in "2 yıl hilâfet görevini” (15) yerine getirdiğinden söz edilir. Hz. Ömer, İslam'ın ikinci halifesi ve hayatta iken cennetle müjdelenen on kişiden biridir. Önceleri koyu bir İslam düşmanı olan Ömer, İslam'ı seçen kırkıncı kişidir. İslamiyet onunla birlikte açıktan açığa söylenir hâle gelir. Zamanında birçok yer fethedilir. Doğruluk ve adaletiyle tanınan Hz. Ömer, on yıl (634 - 644) halifelik yapar. "Faruk" (haklıyı haksızdan ayıran) lakabıyla tanınır. Fakir bir hayat yaşar, halifelik yılları Müslümanlar için huzur devri olur (Pala, 1995: 438). Anlatıda Hz. Ömer'in iki yıl yaptığı söylenen halifelik, gerçekte on yıl yapılmıştır. Hz. Ömer'e yapılan göndergede tarihsel bilgilerde dönüşüm yapılarak anlatının içine sokulmuştur.

c. Hz. Osman: Anlatıda İslam'ın üçüncü halifesi ve hayatta iken cennetle müjdelenen on kişiden biri olan Hz. Osman'a şöyle göndergede bulunulur: “Ömer'in iki yıl hilâfet görevini müteakiben bu görevi Osman 13 yıl sürdürdü. Sonunda onu da şehit ettiler” (15). Hz. Osman, beşinci Müslüman olan kişidir. Ticaretle uğraşmış ve zengin olmuştur. Hz. Peygamber'in iki kızı Rukiye ve Ümmü Gülsüm ile evlendiği için “Zü’n-nûreyn” (iki nur sahibi) unvanıyla anılır. Hayâ ve hilm sahibi biridir. Kur'an-ı Kerim'i çoğaltıp önemli merkezlere gönderir. Malını ve mülkünü İslam uğruna harcar (Pala, 1995: 436). Hz. Osman 644 - 656 yılları arasında halifelik yapar.

c. Hz. Ali: Cebrail, Cafer'in geleceği ile ilgili haberi Hz. Peygamber'e getirdiğinde Cafer'in özelliklerini anlatır. Cafer uzun boylu, güzel yüzlü, buğday renkli bir yiğit olacaktır. Bu yiğit heybette Ali gibidir (14). Hz. Ali dört büyük halifenin sonuncusu, Hz. Peygamber'in amcasının oğlu ve damadıdır. İslamiyet'i kabul eden ilk dört kişiden biri olan $\mathrm{Hz}$. Ali, "Esedullah" (Allah'ın arslanı) lakabıyla bilinir. Hayattayken cennetle müjdelenen on kişiden biridir. Hz Peygamber'in hicreti esnasında, onun yatağına yatarak hayatını tehlikeye atar, böylece Hz. Peygamber'in hayatını kurtarır. Birçok gazâya katılarak özellikle Hayber'de destanlaşan sancaktarlık yapar. Edebiyatımızda kahramanlık ve velilik - imamlık yönleriyle adından sıkça söz edilir. Şairler övecek kişileri birçok bakımdan ona benzetirler. Özellikle tasavvufi edebiyatta ayrı bir yeri vardır. Birçok tarikat, kendisini silsile yoluyla Hz. Ali'ye dayandırır (Pala, 1995: 32 - 33). Destanda, anlatı kahramanı Cafer, heybet bakımından İslam 
kahramanlarından Hz. Ali’ye göndergede bulunularak ona benzetilmiştir. Cafer'in soyu, Hz. Ali ve çocukları üzerinden Hz. Peygamber'e dayandırılmaktadır.

\subsection{Sahabeler}

a. Hz. Hamza: Heybet bakımından Hz. Ali'ye benzetilen Cafer, pehlivanlıkta Hz. Hamza gibidir (14). Hz. Hamza Mekke'de hatırı sayılır, kuvvetli ve çevresinde saygınlık uyandıran birisidir. Onun Müslüman olmasıyla İslamiyet kuvvet kazanır. Medine'ye hicret eden Müslümanlar arasında o da yer alır. Bedir Gazâsı'nda büyük kahramanlıklar gösteren Hz. Hamza, Uhud Gazâsı'nda birçok müşriki öldürdükten sonra Vahşî tarafindan şehit edilir. Kahramanlıklarıyla tanınan Hz. Hamza, ölümüyle Hz. Peygamber'i çok üzmüştür. Adı destanlaştırılmış; onun savaşlarını, yiğitliklerini ve maceralarını anlatan "Hamzanâme”ler yazılmıştır (Pala, 1995: 231). Hz. Hamza da Hz. Ali gibi kahramanlığıyla tanınır. Cafer gibi bir yiğidin güç ve cesareti de böyle kahramanlara göndergede bulunularak anlatılır. Anlatının başka bir yerinde ise Cafer savaşmaya giderken "Hamza'nın giydiği otuz altı parça savaş ve silah elbiselerini eksiksiz" (30) kuşanır.

b. Hz. Fatma: Seyyit, bir devin elinde tutsak olan kırk kız ile oğlanı kurtarırken bunlar daha önceden Seyyit'i tanırlar. Rüyalarında Fatımatüz'z-Zehra'yı görmüşlerdir. O, tutsaklara Battal'ın gelip onları kurtaracağını söyler (254). Hz. Fatma, Hz. Peygamber'in dört kızının en küçüğüdür. Babasına çok benzemesinden dolayı "Ümmü Ebiha" (babasının annesi) diye çağrılırmış. Aklı, güzelliği ve takvası ile tanınır. Hz. Ali ile evlenir. Hz. Peygamber'in soyu onunla devam etmiştir (Atasoy vd., 2014: 589 - 594). Hz. Fatma, tutsaklara rüyalarında görülerek, rüyaların en önemli işlevlerinden biri olarak, gelecekle ilgili haber verir. Daha önceden tutsaklara rüyalarında Seyyit tarafından kurtarılacakları haberi verildiğinden dolayı Seyyit görüldüğünde şaşkınlık ve heyecan yaşanmaz.

c. Hz. Ayşe: Hz. Fatma'nın rüyada tutsaklara haber vermesine benzer bir motif de Hz. Ayşe'de karşımıza çıkar. Seyyit, bu kez halifenin kızını kurtarmaya gittiğinde kız, bir gece önce bir rüya görür. Rüyasında Ayşe-i Sıddık’1 görür. Hz. Ayşe, kıza Seyyit'in gelip onu kurtaracağını söyler (310). Hz. Ayşe, Hz. Peygamber'in mübarek hanımıdır. Hz. Ebubekir'in kızıdır. Hz. Ayşe ilim, ahlak ve fazilet bakımından eşsizdir. Hadis ve fıkıh alanında talebeler yetiştirir. Hz. Peygamber onu çok sever ve över (Atasoy vd., 2014: 610 - 617). Hz. Fatma'nın rüyadaki işlevinin benzeri bu kez Hz. Ayşe'de tekrar edilmiştir.

\subsection{Diğer Kişiler}

a. Amr: Anlatının başında Cebrail tarafında Hz. Peygamber'e doğacak olan Cafer'den bahsedilirken "Bu yiğit[in] pehlivanlıkta Hamza gibi, heybette Ali gibi, kurnazlıkta Amr'dan 
üstün olaca[̆̆g]" (14) belirtilir. Amr "Arapça gramerde örnek verilirken kullanılan belirsiz bir erkek adıdır. Amr'dan başka Zeyd ve dişi olarak da Hind adı kullanılır. Osmanlı geleneğinde fetvâ verilirken, şeyhülislamlar fetvâ isteyenin adını kullanmaz yerine mevhum kişiler olan Amr, Zeyd ve Hind vs. isimlerini kullanılırlardı" (Pala, 1995: 37). Pehlivanlık ve heybet kahramanda bulunması gereken olumlu nitelikler olduğundan bu özellikleri temsil eden kişilerin adları (Hamza ve Ali) verilir. Ancak kurnazlık çoğu zaman kahramanda bulunması gereken olumlu bir nitelik olarak görülmez. Bu bakımdan kurnazlık yönüyle bilinen bir kimseye benzetme yerine, Arapça gramerde belirsizlik bildiren bir kişi adının yerine kullanılan Amr ismi tercih edilir.

b. Zaloğlu Rüstem: Kayser'in kızı Ketayun, Seyyit'i tanımlarken onun erlikte Zaloğlu Rüstem gibi olduğunu söyler (208). Zaloğlu Rüstem, Şehnâme'de adı çokça geçen efsanevî kahramanlardan biridir. Edebiyatımızda acı kuvvet ve yenilmezliğin simgesi olarak anılır (Onay, 1996: 76). Burada Seyyit’in büyük bir yiğit olduğu anlatılmıştır.

c. Hatem-i Tai: Ketayun, Seyyit'i Zaloğlu Rüstem'e benzetirken Hatem-i Tai'ye de göndergede bulunur. Seyyit'in Hatem-i Tai'den ve Peygamber neslinden olduğu belirtilir (208). Hatem-i Tai, Arapların Tay kabilesinden olan, cömertliğiyle tanınan bir kişidir. Çok zengindir. Edebiyatımızda kerem ve sehavetin timsali olarak geçer (Onay, 1996: 260). Seyyit'in Hatem-i Tai ile anılması onun cömertliğini gösterir.

ç. Aristotales: Seyyit, düştüğü kuyuda karşısına çıkan sarayın ortasında bir mermer direk üzerinde İskender-i Zülkarneyn tarafından yazılan yazıları okuduğunda, Aristotales'in onun veziri olduğundan bahsedilir (253-254). Aristotales, eski Yunan filozoflarının meşhurlarındandır. "Melikü'l-Hükema" lakabını alır. Eflatun'un derslerini takip eder, zamanının bütün ilimlerini öğrenir. Doğuda akıl, ilim, isabetli görüşe sahip olmanın timsali olarak edebiyatta adı anılır. Meşhur İskender'in talim ve terbiyesiyle memurmuş (Onay, 1996: 104). Vezirler bağlı bulundukları hükümdarlara daima doğruyu göstermekle mükelleftirler. Onlar aynı zamanda akıl ve bilgeliğin temsilcisidirler. İskender-i Zülkarneyn gibi büyük bir hükümdara da Aristotales gibi akıllı, ilim sahibi bir vezir yakışacaktır.

d. İskender-i Zülkarneyn: Eski kültürümüzde iki İskender bilinmektedir. Birincisi İskender-i Zülkarneyn, diğeri de İskender-i Yunanî'dir. Hayatları, yaşadıkları bölgeler ve başarıları bakımından birbirine benzeyen bu kişiler çok defa aynı kişi sanılmışlardır. Fakat birbirleriyle hiçbir alakaları yoktur. İskender-i Yunanî içki içen, adam öldürmekten zevk alan, adaletsiz biri iken; İskender-i Zülkarneyn bir peygamber veya salih bir kuldur. İskendernâmelerde, İskender, İran asıllı bir Yunan prensidir. Aristo'nun ilmî terbiyesi altında yetiştirilir (Pala, 1995: 287 - 288). Yazının İskender-i Zülkarneyn tarafından yazılması, yazıya 
bir kutsallık kazandırır. Kutsal bir kişi tarafından yazılan yazı, Seyyit’i bulunduğu kuyudan kurtaracak şifreleri de içinde barındıracaktır.

e. Nemrut: Seyyit, Kayser üzerine sefere çıkarken şöyle dua eder: "Ey Bar-i Hüda! Sen padişahların en yücesisin! Nemrud kâfiri öyle zayıf kıl ki, senin kahrından yaratılmış kavmi alt etmeye firsat bulayım..." (316). Bu ifadelerde Bizans Kayser'i Nemrut'a benzetilir. Nemrut, Babil şehrinin kurucusu ve hükümdarıdır. İlahlık davasında bulunan Nemrut, Hz. İbrahim'in dine davetine önem vermez; onu yakalatıp ateşe attırır. Hz. İbrahim Allah'ın emriyle ateşte yanmaz, ateş gül bahçesine döner. Rivayete göre Allah, Nemrut'a bir sivrisinek musallat eder; küçük hayvan Nemrut'un burnundan beynine girer. Nemrut, her hareket edişinde sinek onu rahatsız eder; bundan kurtulmak için başını tokmakla vurdurur (Onay, 1996: 279). Nemrut, Allah'a inanmayıp ilahlık davasında bulunduğundan dolayı Kayser ona benzetilmiştir.

\section{Battal Gazi Destanı'nda Anıştırmalar}

Anıştırma, metinlerarasılığın çokça kullanılan bir biçimidir. Anıştırmada anıştırılan metin ile anıştıran metin arasında bir söyleşim oluşur. Varlığını belirtecek bir dış bildiri dizgesinin olmayışı anıştırmayı bulmayı zorlaştırır. Burada okuyucunun kişisel birikimi ile çabası önemlidir. Anıştırmada açık seçik bir gönderme bulunmaz. Anıştırmada kişi ya da nesneler doğrudan belirtilmez, yalnızca varlığı telkin edilir. Bir şeyi doğrudan belirtme gönderge; bir sözcük alıntılanmadan, bir yapıtın kimliği söylenmeden, açıkça belirtmeden anılması anıştırmadır. Anıştırmada bir şey onu düşündüren başka bir şey aracılığıyla kafada çağrışım yaptırılır. Anıştırmada örtük bir gönderme, kapalı bir anlatım, kapalı bir sezdirim söz konusudur. Bir resme, müzik parçasına, duyguya, bilime, siyasete, dine ve daha birçok konuya anıştırma yapılabilir. Anıştırma başka metinlere gönderdiğinden metinlerarası ilişkiyi işin içerisine sokar. Anıştırma, bir metnin unsurlarını çağrıştırılan başka bir metinle bağlantıya getirir. Anıştırılan her sözcük, yeni bağlamda az veya çok bir dönüşüme uğrar. Anıştırma araştırılırken önce onu belirten bir iz saptanır, okur bu unsurdan yola çıkarak onu araştırıp bulmaya çalışır. Bir isim veya bir başlık bir yazınsal anıştırma olarak ana metnin belirleyici bir metinlerarası unsuru olabilir. Anıştırma alıntı gibi açık ya da sözcüğü sözcüğüne yapılan bir gönderge değildir. Alıntının dolaylı bir biçimidir. Burada iki sözce yan yana getirilmez, üst üste konur. İki düşünce arasında bir yakınlaşma yapılır. Anıştırma bir yarım alıntıdır. Bir metni bütünüyle değil; kısmen, tam belirtmeden alıntılar. Okur ipuçlarından yola çıkarak bütünü tamamlamaya çalışır. Çoğu zaman tek bir sözcük üzerinde oynanan bir oyundur (Aktulum, 2007: 108 - 116). Bu bilgiler 1şığında Battal Gazi Destanı'nda aşağıdaki unsurlar anıştırılmıştır:

2.1. Vak Vak Ağacı: Anlatıda düşmanlar, ancak Seyyit'in yokluğunda Müslüman askerlerine üstünlük sağlar. Seyyit'in varlığında düşmanlar her zaman bozguna uğrar. Bir 
anlamda Müslümanların galip gelmeleri Seyyit'in varlığıyla paralellik gösterir. Yine Seyyit'in bulunmadığı bir anda Kayser'in askerleri iki bin Müslüman'ı yakalar ve öldürür. Başlarını da bulundukları köşkün ağaçlarına asarlar. Seyyit gelince insan başları asılmış ağaçları görür (78). İnsan başlarının ağaçlara asılması, vakvak ağacını anıştırmaktadır.

Rivâyete göre Çin adalarından olan Vakvak adasında yetişen bu ağaç, sabahleyin yeşil ve teravetli, akşamları da solgun olurmuş. Ağacın meyveleri insan şeklinde imiş. Yaprağı incire benzer, martta da meyve vermeye başlarmış. Meyvesi önce, iki insan vücudunu ayaktan başa doğru tamamlarmış. Salkım ağaç gibi sarkan bu meyveler güzel kadın vücutlarını andırır ve haziran başlarında ağaçtan 'vakvak' sesleri çıkararak düşmeye başlarlarmış (Pala, 1995: 556).

Vakvak, Farsça "korkak adam" anlamına gelmektedir. 1656 tarihinde Yeniçeri isyanında İstanbul Sultan Ahmet Meydanı'nda Avcı Sultan Mehmet'e zorla öldürttükleri saray ağalarının çınar ağacına baş aşağı asılmasından dolayı buradaki ağaca "şecer-i vakvak" denilmiştir (Pakalın, 1993: 581). Anlatıda geçen insan başları asılmış ağaç, Sultanahmet meydanında asılan kişilerin başlarının asıldığı ağacı anıştırmaktadır.

2.2. Hz. Yusuf Kıssası: Seyyit, Taryun tarafından zindana atıldığında zindandakilere peygamberi düşte gördüğünü, Hz. Peygamber'in kendisine "Gerektir ki Rum vilayeti senin elinden dalaletten kurtulacak... Kiliseleri yıkıp yerine mescitler yapacaksın” (119) dediğini aktarır. Bu olay Hz. Yusuf'un kıssasını anıştırır. Hz. Yusuf, çocukken rüyasında on bir yıldız ile güneş ve ayı kendisine secde ederken görür. Rüyasını babası Hz. Yakup'a anlatır, babası rüyasını diğer kardeşlerine anlatmamasını söyler. Yusuf'un on bir üvey kardeşi ile Bünyamin adlı bir öz kardeşi vardır. Üvey kardeşleri, babalarının Yusuf’a olan düşkünlüğünü kıskanarak ona kötülük etmeyi planlarlar. Onu gezinti bahanesiyle götürdükleri bir kuyuya atarlar. Babalarına kanlı gömleğini getirerek onu bir kurdun yediğini söylerler. Gelişen olaylar sonucunda Yusuf, önce zindandaki bazı rüyaları, sonra da Mısır hükümdarının rüyasını doğru yorumlayarak Misır'a vezir olur. Hikâyenin sonunda Yusuf'un kardeşleri onu selamlar, çocukluğunda gördüğü rüya böylece gerçekleşir (Daşdemir, 2012: 249 - 284). Hz. Peygamber'in Seyyit'e Rum vilayetini dalaletten kurtaracağını söylemesi, Hz. Yakup'un Hz. Yusuf'un rüyasını kardeşlerinin ona itaat edeceği şeklinde yorumlamasını anıştırmıştır. Her iki rüya da anlatının sonunda gerçekleşecek, Hz. Yusuf'un kardeşleri ona tâbi oldukları gibi Rum vilayeti de İslam ordusuna tâbi olacak, dalaletten kurtulacaktır.

2.3. Hz. Muhammed'in Mucizeleri: Taryun'un kızı zindandaki Seyyit'ten dinine girmesini ister. Seyyit bunu reddeder, onun Müslüman olmasını ister. Kız, Seyyit'e Tanrı'dan bir nesne istemesini, bu nesnenin de gaipten gelmesini ister. Seyyit Allah'a dua eder. Zindanın 
duvarı yarılır, bir sini yemek gelir. Seyyit ve kız o yemekten yerler. Zindanda bulunanlar da karınlarını doyururlar. Sonra sini kaybolur. Kız daha sonra Hz. Peygamber'i düşünde görür ve Müslüman olur (121 - 122). Zindanın duvarından gelen bir sini yemekle zindanda bulunan herkesin doyması, Hz. Peygamber'in bazı mucizelerini anıştırmaktadır. Hz. Peygamber yanında Hz. Ebubekir ile Mekke'den Medine'ye hicretleri esnasında kavurucu sıcaklık altında çölde yol almaktadır. Konaklama esnasında yakınlarında bulunan bir çobanın sürüsünü otlattıkları görülür. Hz. Ebubekir, çobanın yanına giderek ondan biraz süt vermesini ister. Çoban yakınındaki bir keçiyi göstererek sadece süt veren bu keçinin olduğunu; ancak gebe kaldığı için sütünün kesildiğini söyler. Hz. Ebubekir, buna rağmen sağmak için izin ister. Çobanın izin vermesi üzerine Hz. Ebubekir keçiyi Hz. Peygamber’e götürür. Hz. Peygamber ellerini keçinin memelerine götürür, dua eder. Hayvanın memeleri bir anda sütle dolar. Sağılan sütle orada bulunanlardan hepsi doyasıya içer (Suruç, 2006a: 425). Başka bir olayda da Hz. Peygamber, Medine'ye hicret ettikten sonra zaman zaman Medineli Müslümanlara ziyafet verir. Ebu Eyyup, bir gün Hz. Peygamber'e yemek getirir. Ancak getirilen yemek sadece ona ve Hz. Ebubekir'e yetecek kadardır. Hz. Peygamber önce yemeğe otuz kişinin çağrılmasını emreder. Gelen otuz kişi doyuncaya kadar yerler. Hz. Peygamber bu kez altmış kişinin çağrılmasını ister. Ardından yetmiş kişi daha çağrılır. İki kişilik yemekten yüz seksen kişi yer ve hepsi de doyarak yemekten kalkarlar (Suruç, 2006b: 24 - 25). Anlatıda gaipten gelen bir sini yemekle zindanda bulunanların hepsinin doyması, yukarıda anlatılan iki mucizeyi (Hz. Peygamber'in buna benzer birçok mucizesi vardır) anıştırır.

2.4. Dede Korkut Anlatıları: Anlatıda geçen bazı olayların Dede Korkut anlatılarında geçen bazı motifleri anıştırdığı görülür. Seyyit, Emir Ömer'in kızını kendisine ister. Emir Ömer, kızını vermeye pek yanaşmaz. Onun için, ona güç şartlar koşar. Karısı, Emir Ömer'e Seyyit’ten şunları getirmesini ister: "Hindistan'da ak fil vardır. Onun üstünde kızıl altından çadır-1 hümayun, ayağında da altın halhal vardır. Onu getirmesini iste. İkinci olarak, yüz kıvırcık tüylü deve, dört yüz Arabi at ve her birinin üzerinde güzel olan elli kızı alsın, bunları getirsin" (184). Seyyit kendisinden bunları getirmesi için bir yıl vade ister. Emir Ömer'in Seyyit Battal Gazi'den istedikleri Dede Korkut anlatılarından “Kam Pürenün Oğlı Bamsı Beyrek”te Pay Piçen'ün kızı Banı Çiçek için kardeşi Delü Karçar'ın istediklerini anıştırır. Delü Karçar, kız kardeşi için Dede Korkut'tan şunları getirmesini ister: "Bin buğra, getürün kim maya görmemiş ola, bin dahı aygır getürün kim hiç kısrağa aşmamış ola, bin dahı koyun görmemiş koç getürün, bin de kuyruksuz kulaksuz köpek getürün, bin dahı püre getürün” (Ergin, 1997: 126 - 127).

Anlatıda Hamiran adlı bir beyin Aden Banu adlı bir kızı vardır. O kız evleneceği erkekte şunu arar: "Her kim beni mağlup ederse, benim helâlim odur" (204). Seyyit yolda bir 
yiğitle karşılaşır. Onunla dövüşür, onu yener. O kişinin başını açtığında onun çok güzel bir kız olduğunu görür. Kız, Seyyit’ten kendisini almasını ister. Seyyit onu Bederun Şah'a vereceğini söyler. Daha sonra kız, kendisiyle evlenmek isteyen Firenk mâlikinin oğlu ile Çayi mâlikinin oğlunu yener. Arkasından Bederun atını meydana sürer. Malının çok olduğunu ve kendisiyle evlenmesini ister. Kız "Bana mal gerekmez, er gerekir. Şunu bil ki seni de diğerleri gibi yaparım" (205) der. Kız, Bederun'u da yener; tam başını kesecekken Seyyit meydana girer. Seyyit kızı yener. Kızı Bederun'la evlendirir. Kızın evleneceği erkekle çeşitli yarışlara girmesi ve ancak kendisini yenecek erkekle evlenmesi birçok anlatıda karşımıza çıkan bir motiftir. Bu motif Türklerin kahramanlığa verdiği değerin bir sonucudur. Kadın evleneceği erkekte yiğitlik arar. Ancak kendisinden daha güçlü birisiyle evlenebilir. Bu olay da Dede Korkut anlatılarından "Kam Pürenün Oğlı Bamsı Beyrek” anlatısını anıştırır. Bamsı Beyrek bir gün geyik kovalarken bir kırmızı otak görür. Bu otak yavuklusu Banı Çiçek'in otağıdır. Banı Çiçek kendisini dadı olarak tanıtır ve Bamsı Beyrek'le yarışır. Eğer kendisini yenerse Banı Çiçek’i de yeneceğini söyler.

At depdiler, Beyrek atı kızun atını kiçdi. Oh atdılar, Beyrek kızun okın yardı. Kız aydur: Mere yiğit menüm atumı kimse kiçdügi yok, ohumı kimse yarduğı yok, imdi gel senün ile güreş tutalum didi. Haman Beyrek atdan indi. Karvaşdılar, iki pehlivan olup bir birine sarmaşdılar. Beyrek götürür kızı yire urmak ister, kız götürür Beyregi yire urmak ister. Beyrek bunaldı, aydur: Bu kıza basılacak olur-isem Kalın Oğuz içinde başuma kahınç yüzüme tohınç iderler didi. Gayrete geldi, kavradı kızun bağdamasın aldı, emceğinden tutdı. Kız koçındı. Bu kez Beyrek kızun ince biline girdi, bağdadı arhası üzerine yire urdı (Ergin, 1997: 123).

Kız, kendisinin Banı Çiçek olduğunu söyler. Bamsı Beyrek kızın parmağına yüzük takar. Yapılan anıştırmada aynı zamanda anlamsal dönüşüm yapılmıştır. Banı Çiçek, evleneceği erkeğe yarışmaların tümünde yenilmesine rağmen, Aden Banu evleneceği erkek Bederun Şah'1 her iki mücadelesinde de yenmeyi başarır. Aden Banu, Seyyit Battal'ın isteği ile yendiği erkekle evlenmeyi kabul eder. Ayrıca destanda geçen Aden Banu ismi, Banı Çiçek ismini anıştırır.

Seyyit, bir gün denizin kenarında iken denizden bir sandık gelir. Sandığı dalgalar kenara iter. Seyyit sandığın kapağını açar, içinden güzel yüzlü bir yiğit çıkar. Yiğidin bir zamanlar babasının oğlu kızı olmamış. Babası çocuğunun olması için kurbanlar kesmiş, sadakalar vermiş. Sonunda annesi hamile kalmış. Çocuk ilk doğduğunda bir işkembe gibiymiş, başı ayağ 1 belirsizmiş. Vücudunda sadece iki delik varmış. Birinden nefes alır diğerinden cerahat edermiş. Hekim ve cerrahlar tarafından buna bir anlam verilmemiş. Babası bir gün avda dört dervişle karşılaşmış. Bunların adları Musa, İsa, Davut ve Muhammed'miş. Babası bunların dördünden de dua istemiş, oğlu hangisinin duasıyla şifa bulursa onun dinine girecekmiş. Çocuk 
Muhammed'in duasıyla şifa bulmuş, bu işkembenin içinden çıkmış (267). Dede Korkut anlatılarından "Basat Depegözi Öldürdügi Boy”da geçen Tepegöz bu yiğidi anıştırır. Anlatıya göre Aruz'un bir çobanı vardır. Konur Koca Saru Çoban adındaki bu çoban, yaylaya çıkma zamanı gelince herkesten önce yaylaya çıkarmış. Bir gün yaylaya çıkma zamanında Saru Çoban'ın sürüsü Uzun pınar denen bir pınara gelince ürkmeye başlar. Çünkü periler pınara konmuşlardır. Çoban peri kızlarından birini yakalar ve onunla münasebette bulunur. Çoban ertesi yıl pınarın başına geldiğinde peri kızı çobandan olan çocuğunu dünyaya getirmiştir.

Çoban ilerü vardı. Gördi-kim bir yığanak yatur, yıldır yıldır yıldırur. Peri kızı geldi aydur: Çoban amanatun gel al, amma oğuzun başına zaval getürdün didi. Çoban bu yığanağı göriçek ibret aldı. Girü döndi, sapan taşına tutdı. Urdukça böyüdi. Çoban yığanağı kodı kaçdı. Koyun ardına düşdi (Ergin, 1997: 207-208).

O sırada Bayındır Han beyleriyle gezintiye çıkmıştır. Bu pınarın başına geldiklerinde bu nesneyi görürler.

Gördiler kim bir ibret nesne yatur, başı göti belürsüz. Çevre aldılar. İndi bir yiğit bunı depdi. Depdükçe böyüdi. Birkaç yiğit dahı indiler depdiler. Depdüklerince böyüdi. Aruz Koca dahı inüp depdi. Mahmuzı tokındı, bu yığanak yarıldı. İçinden bir oğlan çıkdı, gevdesi adam depesinde bir gözi var (Ergin, 1997: 208).

Battal Gazi Destanı'ndaki doğduğunda bir işkembeyi andıran, başı ayağı belirsiz nesne; peri ile insanın birleşmesinden doğan Tepegöz'ün doğduğundaki görünüşünü anıştırır. Ancak bu motifte de bir dönüşüm meydana gelmiştir. Battal Gazi Destanı'ndaki yiğit büyüdüğünde çok güzel yüzlü bir kişiye dönüşmesine rağmen, Dede Korkut anlatısında Tepegöz Oğuz halkının başına bela olan bir ucubeye dönüşür.

2.5. Hz. İbrahim - Nemrut: Seyyit, bir şehre varır. Şehrin beyinin adı Mihrasep'tir. Beyin gözü Seyyit'e takılır. Seyyit'in boyu posu beyin hoşuna gider. Bey, bir kuluna onu odasına götürerek hoş tutmasını ister. Kul, Seyyit'in yanına gelir; padişahın onu makamına çağırdığını söyler. Seyyit, padişahın dinini sorar. Onun putperest olduğunu öğrenir. Padişahın kızıl altından kırk batman ağırlığında bir putu vardır. İçi dolu ve süslüdür. Hiçbir şahın böyle putu yoktur. Seyyit, padişahın kâfir olduğunu, onun kapısına varmayacağını söyler. Kul, Seyyit'e sövmeye başlar. Seyyit, bunun üzerine kâfirin iki kulağını koparır, eline verir. "Madem ki tanrı olarak biliyorsunuz, var o puta söyle kulağını yerine getirsin” (186) der. Bu olay Hz. İbrahim ile babası ve Nemrut arasında geçen hadiseleri anıştırır. Hz. İbrahim'in babası Azer, put haneyi andıran evlerinde putlar yapar; bunları satarmış. Babası bazen de onu putları satmak için pazara yollarmış. İbrahim değer vermediği bu ağaç ve taş parçalarının boyunlarına birer ip geçirir, onları sürüyerek götürürmüş. Babasının uyarılarına rağmen İbrahim, bunların kimseye 
faydası olmadığını, Allah'a inanmasını söylermiş. Bunun üzerine babası onu yanından kovmuş. Bir gün İbrahim kimselerin olmadığını görüp put haneye girmiş. Oradaki tüm putları paramparça etmiş. Sonra da elindeki baltayı en büyük putun boynuna asmış. İnsanlar durumu öğrenince feryat ederek bunu İbrahim'in yapmış olabileceğini düşünmüşler. Kral Nemrut da olanları duymuş, İbrahim'i yakalatmış. İbrahim'i huzuruna getirtmiş. İbrahim bu işi büyük putun yaptığını söylemiş. Ama oradakiler putların hareket etmediğini söylemişler. İbrahim zindana atılmış (Efe, 2007: 71 - 78). Her iki olayda da putların cansız varlıklar olduğu, kimseye yardımlarının dokunmayacağı anlatılmıştır. Ne destandaki padişahın kızıl altından kırk batman ağırlığındaki putunun ne de Azer'in put hanesinde bulunan en büyük putun kimseye faydası olmuştur.

2.6. Hallacoğlu Mansur: Seyyit'i esir eden Kayser, onun boynunu vurmak istediğinde veziri Yemliha, şunları söyler:

Ey şah! Bunun kanını yere dökmeyin, Taryun ateşte yaktı, ölmedi. Akabe Kadı, ağu verdi, ölmedi. Bunun kanını yere dökersen kanı toprağa karışır, topraktan ot biter, o otu koyun yer, o koyunu da insan yer; insanda şehvet hasıl olur, şehvetten yine Battal olur (215).

Buradaki olayda Hallacoğlu Mansur ile ilgili anlatılan bir söylentiye anıştırma yapılmıştır. Hallacoğlu Mansur edebiyatta adı çokça anılan bir sûfîdir. Tasavvuf yoluna çok erken giren Mansur, zühd ve itikaf ile çabucak ilerleme kaydeder. Hakkında birçok menkıbe vücuda getirilir. Tasavvuf yolunda ilerleyen Mansur, "Ene'l-Hakk" (Ben Hakkım) deyince hapse atılır. Daha sonra idama mahkûm edilir. Rivayete göre Hallac'ı darağacına çekmeden evvel ellerini keserler. Bileklerinden akan kan yerde kelime-i tevhidi yazar. Kanın ardı arkası kesilmez. Kanlar Dicle nehrine karışır, nehir kelime-i tevhidi söyleyerek coşar. Civardaki bitkilere ulaşır, bitkiler de kelime-i tevhidi söylemeye başlar. Halk bunu bir türlü durduramaz. Mansur'un bir beytinde küllerini Dicle'ye döktüklerinde nehrin coşkunluğunun biteceğine dair bir işarete rastlanır. Sonunda cesedi yakılır, külleri nehre savrulur. Ancak o zaman her şey normale döner (Pala, 1995: 226). Battal'ın kanının yere dökülmesiyle toprağa karışıp birtakım evrelerden sonra tekrar Battal'a dönüşmesi, Hallacı Mansur'un kanının coşkunluğunun bir türlü durdurulamamasını anıştırır. Bu anıştırma bir anlamda Battal'ın Hallac'la benzerlik kurularak onun hak yolunda olduğunu da gösterir.

2.7. Şah Maran: Düşman askerleri, Seyyit'i bir tahtaya bağlar; kuyunun üstüne getirirler. Cellatlar ellerinde k1lıçları Seyyit'in boynunu vurmak için beklerler. Cellatlardan biri Seyyit'in boynunu vurmak için gelir, boynunu vurmak için hamle yaptığında Seyyit'in üstüne düşer, ikisi de kuyuya düşerler. Kayser'in emriyle üzerleri büyük taşlarla kapatılır. Seyyit 
kuyuya düştüğünde üç kere "Kulhuallahuehad"1 okur. Kuyunun dibinde balçığa gömülür. Kırk adım yürür, duvar dibine gelir oturur. Hiç durmadan Kur'an okumaya devam eder. O anda bir 1ş1k belirir, sesler duymaya başlar. Bu sesler yılanların sesleridir. "Ayete'l-Kürsi”yi okur, üfler, parmağıyla bir daire çizer, içine girer. Yılanların bir kısmı ejderhaya benzemektedir. Bir ejderha ve sırtında küçük bir alaca yılan ona doğru yaklaşır. Bunun sağ ve solunda da yılanlar vardır. Ejderhanın sırtındaki küçük yılan, Seyyit'e yaklaşır ve onunla konuşur:

Ey gaziler sultanı Seyyit Battal Gazi, nasılsın? Kaderde buraya düşmen ve acayiplikler görmen varmış. Benim adın Yemliha'dır, lakabıma da Şah Maran derler. Bu gördüklerin benim askerlerimdir. Süleyman Nebi'den sonra Belukiye ve Affan beni tuttular, kırk gün dağda ve taşta gezdirdiler. Hangi ot şifalı menfaatlı veya neye yaradığını bana bildirdiler, yazdılar. Sonunda Hak Teâla bize kurtulma firsatı verdi, kurtuldum, geldim, bu kuyuya girdim. Bir defa da dışarı çıktım, o iki cihanın övdüğü Muhammed Mustafa'yı ziyaret ettim. Sonra yine buraya geldim. Buraya Cehennem kuyusu derler. Bunun bir kapısı Kaf Dağı'na açı1ır (219-220).

Şahmaran, yılanların şahıdır. Efsaneye göre Yemliha adında insan başlı bir yılan varmış. Yemliha bir mağarada yeşillikler içinde bir ülkede yaşarmış. Danyal peygamberin hüküm sürdüğü bir dönemmiş. Bir gün Cemşasb bal dolu bir kuyuya rastlamış. Arkadaşları onu bir iple kuyunun dibine indirmişler. Balı çıkardıktan sonra arkadaşları onu kuyuda bırakıp gitmişler. Yalnız başına kuyuda kalan Cemşasb elindeki bıçakla kuyuyu kazmış, delikten bir 1şık görünmüş, deliği genişletince yemyeşil bir yer karşısına çıkmış. Burada Yemliha ile karşılaşmış. Orada yedi sene kaldıktan sonra onun yerini kimseye söylememe şartıyla Yemliha onu yeryüzüne çıkarmış. Uzun yıllar bu sırrı saklamış. Ancak devrin padişahı bir gün hastalanmış. Tek çaresi de Şahmaran'ın eti imiş. Vezir büyü ile Cemşasb'ın Şahmaran'ın yerini bildiğini öğrenmiş ve zorla yılanı ele geçirmiş. Şahmaran suçun Cemşasb'da olmadığını öğrenmiş. Ona etini kaynattıklarında ilk suyunu vezire içirmesini, ikincisini kendisinin içmesini, etini de padişaha vermesini söylemiş. İlk suyu içen vezir ölmüş, eti yiyen padişah iyileşmiş, o da vezir olmuş (Pala, 1995: 497 - 498). Anlatıda Şah Maran'ın ismi bir gönderge olarak bulunmasına rağmen bu gönderge bizi ilgili efsaneye götürdüğünden anıştırma olarak değerlendirilebilir. Efsanede Cehennem Kuyusu, Süleyman Nebi, Kaf Dağı geçmez, Şahmaran ise cennet gibi bahçelerin içinde mutlu bir biçimde yaşar. Ancak Battal Gazi Destanı'nda anlamsal dönüşümlerle Şah Maran, Belukiye ve Affan tarafından zorla Cehennem Kuyusu'na atılmıştır. O, burada bir anlamda tutsak edilmiştir. Efsane başka bir anlatıda anıştırma yoluyla yer almış; ancak birtakım dönüşümlerle içinde yer aldığı yeni anlatıda yeni işlevler yüklenmiştir. 
2.8. Hz. Ebubekir - Yılan: Anlatılan olayda ejderhanın sırtındaki küçük yılanın Hz. Peygamber'i ziyarete gitmesi Hz. Peygamber'in hicreti esnasında olduğu söylenen şu olayı da anıştırır: Mekke'den Medine'ye hicretleri esnasında müşriklerden kurtulmak için Hz. Ebubekir ile bir mağaraya sığınan Hz. Peygamber belli bir süre burada saklanır. Hz. Ebubekir mağarada birçok deliğin olduğunu görünce tüm delikleri kumaş parçalarıyla kapatmaya çalışır. Buradan çıkacak bazı hayvanların Hz. Peygamber'e zarar verebileceği endişesiyle açıkta kalan son deliğe de ayağını koyar. Bir süre sonra delikte bulunan yılan Hz. Ebubekir'in ayağını 1sırır, Hz. Ebubekir acıyla ayağını delikten çektiğinde yılan dışarı çıkar ve konuşur. Yı1lardır Hz. Peygamber'i görmeyi arzuladığını, delik kapanınca bu arzusuna kavuşmayacağı için ayağını 1sırdığını söyler.

2.9. Lokman Hekim: Şah Maran'ın anlatıldığg olayda tabiatta bulunan şifalı otların neye yaradığının yılana bildirilmesi Lokman Hekim'i çağrıştırır. Lokman Hekim ile ilgili Kuran-ı Kerim'de bir sûre de vardır. Peygamber olduğu hakkında çeşitli rivayetler olmasına rağmen, genel kanaat onun salih bir kul olduğu yönündedir. Lokman Hekim, hikmet ve hekimliğin piri olarak bilinir. Lokman her derdin devasını bilen bir doktormuş. Bitkilerin dilini anlar, onların konuşmalarını dinler ve hangi otun neyin dermanı olduğunu böylece bilirmiş (Onay, 1996: 339 - 340). Küçük yılanın kırk gün dağda taşta gezdirilmesi; bu esnada hangi otun şifalı, menfaatlı veya neye yaradığının ona bildirilmesi; Lokman Hekim'in bitkilerin konuşmalarını anlayıp onları dinleyerek hangi otun hangi hastalığın şifası olduğunu bilmesini anıştırmıştır.

2.10. Sultan II. Mehmet: Esatur ile Seyyit bir anlaşmaya varırlar. Esatur kendi şehrinde Seyyit'e bir gön miktarı yer verecektir. Seyyit bir sı̆̆ır derisini incecik sırım gibi keser. Uzunluğu dört bin arşın olur. Giderek o şehrin içinde bir yer belirler (238). Seyyit'in etrafını çevirdiği yer oldukça geniş bir alanı kapsar. II. Mehmet ile ilgili şöyle bir söylenti anlatılmaktadır: Söylentiye göre Sultan II. Mehmet Anadoluhisarı'nı yaptırdıktan sonra Bizanslı Konstantin'den Boğaz'ın Avrupa yakasında kendisine bir sığır derisi kadar yer vermesini ister. Konstantin önce bu kadar küçük bir istek olduğu için alay eder. Konstantin, II. Mehmet'in beğendiği yerde bir sığır derisi kadar yer seçmesine izin verir. Sultan II. Mehmet ertesi gün yeniçeri ocağının en usta saracını çağırtır. Ondan bir sığır derisinden tek parça bir sicim yapmasını ister. Usta, deriyi o kadar ince keser ki şu andaki Rumelihisarı'nın tamamını içine alacak şekilde çevirerek hisarı yaptırır. Daha sonra rakibine haber yollayarak şimdilik Boğaz’ın Bizans tarafında bir sığır derisi kadar toprak edindiğini, sıranın Bizans’a geldiğini söyler. Bu anlatının bir benzeri Harun Reşit için de anlatılır. Harun Reşit, Bağdat halifesi iken İstanbul'u kuşatır; ancak alamaz. Bunun üzerine Alina Kral'dan bir sığır postu kadar yer ister. Harun Reşit 
sığır derisini incecik keser ve buraya bir kale yaptırır (Pala, 2003: 225 - 226). Battal Gazi Destanı'nda anlatılan olay İstanbul ile ilgili yukarıda anlatılan iki söylentiyi anıştırmaktadır.

2.11. Hz. Süleyman: Seyyit, denizde yolculuk yaparken karşısına bir ak dağ çıkar. $\mathrm{Bu}$ dağa çıkmak için yol ararken uykusu gelir ve uyur. Düşünde Hz. Ali’yi görür. Hz. Ali ona uyandığında çok garipliklerle karşılaşacağını, su yüzünde bir elma geleceğini, onu alıp yediğinde tüm dilleri konuşabileceğini söyler. Uyandığında su yüzünde bir elma görür, onu yer ve tüm dilleri konuşmaya başlar (269). Dünyanın tüm dillerini bilme motifi Hz. Süleyman’1 anıştırır. Nitekim Hz. Süleyman, kuşlarla, hayvanlarla konuşur; onların dillerini anlarmış. Yukarıda Lokman Hekim'in bitkilerin konuşmalarını anladığı ile ilgili halk arasında yaygın bir inanıştan bahsetmiştik. Bu yönüyle de Lokman Hekim anıştırılmıştır.

2.12. Ashab-ı Kehf: Seyyit; otuz gemi, otuz bin askerle Kaf Dağı'na gitmek için yola çıkar. Bunlar bir gün bir adaya varırlar. Ada çok güzeldir. Seyyit, bir güzel sahra ortasında bir ağaç görür. Ağacın dalları asumana kadar yükselir. Ağacın altında inciden yapılmış ulu bir kubbe vardır. Altında hoş bir pınarın aktığını görür. Birden bire kubbe yarılır, içinden üç pir çıkar. Seyyit'e selam verirler. Seyyit'e: “Hoş geldin, ey Resûlullah'ın oğlu! Cemalini özlemiş̧ik, mübarek yüzünü gördük elhamdülillah” (272) derler. Gökyüzünden bir sofrada üç tabak yemek gelir. Yemeklerini yedikten sonra sofra tekrar havaya yükselir. Seyyit burasının neresi olduğunu sorar. Burası Kaf Dağı'dır. Zülkarneyn türbesi buradadır. Onlar da Zülkarneyn yarenlerindendir. Periler tarafından cemaatleri kırılmış, bunlar da bir mağaraya kaçmışlardır. Bir gün işittikleri bir sesle mağaradan çıkıp bu kubbeye konulmuşlardır. O günden beri beş bin beş yüz y1l geçmiştir. Bu gece düşlerinde Hz. Peygamber’i görmüşlerdir. Seyyit'in geleceğini onlara haber vermiştir (271 - 272). Beş bin beş yüz yıl boyunca bir kubbede kaldıktan sonra bir kişiyle karşıllaşma, Ashab-1 Kehf'i anıştırır. Ashab-1 Kehf, “yedi uyuyanlar” veya “yedi âlimler” olarak da bilinir. Kur'an-ı Kerim'de Kehf sûresinde bunların başlarından geçenler anlatılır. Anlatıya göre Tarsus civarında Dakyanus adlı bir vali, halkının puta tapmasını ve onlar için kurban kesmesini ister. Yedi genç bu emre uymazlar. Bir namazgâha giderek orada günlerini ibadetle geçirip, Allah'a yalvarırlar. Vali bunları çağırıp, emrine uymazsa öldürüleceklerini söyler. Yedi genç bunun üzerine şehirden ayrılırlar. Ayrılırken Kıtmir adlı köpek de peşlerine takılır. Bunlar Neclüs dağında bir mağaraya sığınırlar. Bir müddet sonra uyurlar. Kendilerini takip eden valinin adamları mağaranın ağzını örerler ve bir kaya ile kapatırlar. İçerde kalan yedi kişi ile köpekleri yaklaşık olarak 309 yıl uyurlar. Bir ikindi vakti uyanırlar. Ekmek almak için arkadaşları, Yemliha'yı gümüş bir para ile şehre gönderirler. Elindeki gümüş paradan bunun define bulduğunu sanan firıncı, valiye haber verir. Yemliha olanları anlatır, mağaraya gelirler. Önce Yemliha içeri girer, o sırada hepsi tekrar uykuya dalar ve bir daha da uyanmazlar (Pala, 2003: 
49). Yedi arkadaş ile köpeklerinin 309 yıl boyunca bir mağarada uyumaları, Battal Gazi Destanı'nda üç pirin beş bin beş yüz yıl bir kubbede geçirmeleriyle paralellik gösterir. Battal Gazi Destanı'ndaki üç pire rüyalarında Hz. Peygamber tarafından Seyyit'in geleceği haberinin verilmesi onların iyi birer insan olduğunu gösterir. Ashab-1 Kehf anlatısında da yedi uyurlar günlerini ibadetle geçiren, puta tapmamak için bir mağaraya sığınan Allah'a inanan iyi insanlardır. Bu yönleriyle de iki anlatı arasında bir benzerlik bulunmaktadır. Destanda üç pir, periler tarafından cemaatleri kırılmış; onlar da bir mağaraya kaçmışlardır. Ashab-1 Kehf anlatısında ise Dakyanus adlı putperest, zalim bir valinin zulmünden kaçan yedi arkadaşın bir mağaraya sığındıkları görülür.

2.13. Kerem ile Aslı - Ferhat ile Şirin: Kayser'in kızı, Seyyit'e âşık olur. Düşman Seyyit'in üstüne geldiğinde kız eline küçük bir taş alır, onu uyandırmak için Seyyit'e atar. Taş, Seyyit'in kulağı tozuna dokunur; Seyyit bununla ölür. Kız, Seyyit'in öldüğünü görünce hançerini çıkarır; hançerinin üzerine düşüp şirin canını Hakka teslim eder (318 - 319). Anlatıların sonunda iki sevgilinin birlikte ölmeleri, halk hikâyelerinde yaygın olarak görülen bir motiftir. Kerem ile Aslı hikâyesinde birtakım maceralardan sonra kızını Kerem'e vermek zorunda kalan Aslı'nın babası Keşiş, kızının gerdek gecesi giymesi için bir elbise yaptırır. Kızına elbisenin düğmelerini Kerem'in çözmesi şeklinde nasihatte bulunur. Kırk gün kırk gece düğünden sonra Kerem gerdeğe girer. Kerem, Aslı'nın isteği üzerine elbisesinin düğmelerini sırayla çözmeye çalışır. Ancak düğmeler bir yandan açılırken, diğer yandan tekrar bağlanır. Kerem düğmeleri çözmeyi bir türlü başaramaz; çünkü elbise sihirlidir. Düğmeleri çözmeye çalışan Kerem, sabaha karşı artık dayanamaz ve bir âh çeker. Ağzından çıkan alevle ateş alıp yanmaya başlar. Aslı bazı rivayetlere göre bir, bazılarına göre de yedi veya kırk gün Kerem'in külleri başında bekler. Bir gün küller dağılmasın diye saçlarıyla toplarken kendisi de alev alıp yanar (Duymaz, 2001: 169 - 170). Ferhat ile Şirin hikâyesinde de buna benzer bir son görülür. Hikâyenin sonunda Ferhat'a Şirin'in bazı varyantlarda öldüğü bazılarında ise evlendiği haberi verilir. Dağı delmekte olduğu sırada haberi duyan Ferhat, bazı varyantlarda kendisini külünkle bazılarında ise kayalara vurarak öldürür. Ferhat'ın öldüğünü duyan Şirin kendini hançerle öldürür. Bazı varyantlarda Şirin Ferhat'ın yattığı kulübeye girerek Ferhat'ın üstüne atlar ve ölür (Özarslan, 2006: 86 - 87). Battal Gazi Destanı'nda Seyyit ile onu seven Kayser'in kızının ölümleri (burada da önce erkek ölür, sonra buna dayanamayan kız kendisini öldürür), Kerem ile Aslı, Ferhat ile Şirin gibi halk anlatılarının sonunda âşıkların birlikte ölümlerini anıştırmaktadır.

\section{Sonuç}

Battal Gazi Destanı'nın konusu, Müslüman - Hristiyan savaşlarıdır. Bir tarafta Bizans Kayseri, diğer tarafta İslâm dünyasının Halife'si vardır. Kayser, sık sık ordu hazırlayıp Malatya 
üzerine sefer düzenler. Kayser'in arkasında her defasında çok güçlü bir ordu vardır. Ancak Battal Gazi önderliğindeki İslâm ordusuna her defasında yenilir. Bu menkıbevî metin, Müslüman Türklerin maddi ve manevi fetihlerini konu edinmesinden ve sade dille vücut bulmasından dolayı, devletin en uzak köylerinden sarayına, ordusundan edebiyat dünyasına kadar her muhitinde ilgi görmüş ve okunmuştur. "Türkler tarafından çok sevilmesinin sebebi, Battal Gazi'nin İslâmiyet'in yayılması uğruna kahramanlık göstermesi ve kahramanlığın mekânının Anadolu olmasından kaynaklanıyor görünmektedir” (Demir - Erdem, 2006: 99). Anlatıda kullanılan gönderge ve anıştırmalara bakıldığında Battal Gazi Destanı'nın meydana getirildiği kültür dünyası ile ilgili bilgilere ulaşmak mümkündür. Gönderge ve anıştırmalar çoğunlukla İslam kültür ve medeniyetinde önemli görülen varlık, kişi ve olaylara yapılmıştır. Melekler, peygamberler, ilk dört halife, sahabeler, Türk - İslam kültür dairesine ait halk anlatı kahramanlarına yapılan gönderge ve anıştırmalar, incelediğimiz anlatıda bulunan ideoloji ve anlatılıp dinlendiği / yazılıp okunduğu kültür ve coğrafyanın ipuçlarını vermektedir. Bu anlamda bir metnin içinde yer alan gönderge ve anıştırmalar, metin incelemelerinde göz ardı edilmemesi gereken önemli unsurlardandır. Battal Gazi Destanı, Müslüman Türklerin Anadolu'ya yerleşmek için verdikleri mücadeleler sırasında doğmuştur. $\mathrm{Bu}$ destanda dini yayma ve dine dayalı öğeler ön plana çıkmaktadır. Eski Türk destanlarında görülen millî ülküye dayalı hayat anlayışı ve üstünlük ideali yerini, İslâm tasavvufunun ve İslâm inancının yücelttiği manevi üstünlüğe bırakmıştır. Bu unsurlar anlatıda geçen gönderge ve anıştırmalarla paralellik göstermektedir. Başka bir ifadeyle kullanılan gönderge ve anıştırmalar İslam tasavvufu ile İslam inancının yücelttiği manevi değerleri aksettirmektedir.

1960’lı yıllara kadar çoğunlukla tarihe, yazara, yazarın psikolojisine göre ele alınan metinler; sonraları söylemlerin iç içe geçtikleri, çok sesli bir özellik taşıdığı, anlamın büyük ölçüde önceki metinlerden gelen kesitlere bağlı olarak üretildiği düşüncesinden hareketle incelenmeye başlanır. Metinler artık ayrışık parçaların yeni bir düzende birleşimi olarak algılanır. Her metin çok sayıda metnin kesiştiği bir yerdir. Bir sözce başka sözcelerle sürekli bir etkileşim içerisinde bulunur. Julia Kristeva metni bir alıntılar mozaiği olarak şöyle tanımlar: "Her metin bir alıntılar mozaiği gibi oluşur, her metin kendi içinde başka bir metnin eritilmesi ve dönüşümüdür” (Aktulum, 2007: 41). Belli bir metnin yapısında yer alan kesitler, başka metinlerden alınan çok sayıda kesitin birleşmesinden meydana gelir. Başka metinlere ait unsurlar yeni bir metne sokulurken bir dönüşüm işlemine tâbi tutulur. Önceki yazılardan gelen sözcelerde yeniden dağılım işlemi gerçekleştirilir. Başka metinlere ait unsurlar yeni bir bağlama dönüştürülerek sokulmasıyla yeni bir metin üretilir. Bu bilgiler ışığında yapılan incelemede de görüldüğü üzere, sözlü / yazılı kültürde yaşayan birçok kesit, Battal Gazi Destanı'nın üretilmesinde önemli bir rol üstlenmiştir. İnceleme metni âdeta bir alıntılar mozaiği gibidir. 
Peygamber kıssalarından mitolojik varlıklara, halk hikâyelerinden tarihî olaylara değin birçok farklı alana ait motif; yeni bir bağlamda, yeniden bir dağılım işleminden geçirilerek yeni bir metni oluşturmuştur. Anlatı kendinden önce meydana gelmiş kültür ögelerinden izler taşımaktadır. Önceki metinlere ait sözceler bağlam değiştirerek yeniden dağıtılmıştır. Anlatı eski alıntıların yeni bir örgüsüdür. Daha önce anlatılan / yazılan metinler yeni bir anlamla süslenilerek yeni bir metin üretilmiştir. Türk kültür dünyasının diğer anlatıları üzerine yapılacak çalışmalarda da benzer neticelere ulaşılması muhtemeldir. Özellikle sözlü kültür ürünlerinde benzer motiflerin farklı anlatı türlerinde bağlam değiştirerek yer almaları göz önünde bulundurulması gereken önemli bir husustur. Örneğin, ölüm delili olarak kanlı gömlek motifi, olay ve şahıslar değişse de farklı anlatı türlerinde benzer işlevlerle kullanılmıştır. Kanlı gömlek motifi, her anlatıda içinde kullanıldığı anlatı türünün niteliğine uygun biçime girmiştir (Bars, 2014). Gönderge ve anıştırmaların incelenmesiyle farklı dönem ve coğrafyalarda meydana gelen ürünlerin hangi kültürel ortamda oluşturuldukları ile ilgili bilgilere ulaşmak mümkündür. Sonuç olarak şunları söylemek mümkündür:

1. Anıştırma ve göndergeler vasıtasıyla Battal Gazi Destanı'nın meydana geldiği sosyal, kültürel, dinî çevre ile ilgili bilgilere ulaşmak mümkündür.

2. Battal Gazi Destanı içerisinde kendinden önce oluşmuş kültür ögelerinden izler taşımaktadır.

\section{Kaynaklar}

AKTULUM, K. (2007). Metinlerarası İlişkiler. İstanbul: Öteki Yayınevi.

AKTULUM, K. (2011). Metinlerarasılık / Göstergelerarasılık. Ankara: Kanguru Yayınları.

ARAK, H. (2006). Alman Halk Kahramanı Kral Rother ile Türk Halk Kahramanı Seyyid Battal Gazi'nin Tarihsel Gerçekliği. Millî Folklor, 72, 47 - 57.

ARAK, H. (2010). Kral Rother ve Seyyid Battal Gazi Destanları'nda İstanbul'u Fethetme Mücadelesi. Uluslararası Sosyal Araştırmalar Dergisi, 3 / 11, 33 - 43.

ATASOY, İ. vd. (2014). Sahabiler Ansiklopedisi. İstanbul: Nesil Yayınlar1.

BARS, M. E. (2014). Halk Anlatılarında Ölüm Delili Olarak "Kanlı Gömlek" Motifinin Kullanımı. Turkish Studies-International Periodical For The Languages, Literature and History of Turkish or Turkic, 9 / 9, 259 - 270.

CİCIOĞLU, M. N. (2013). Kırgız Türkçesiyle Yazılmış Olan Seyyid Battal Gazi Destanı Üzerine Bir İnceleme. Turkish Studies-International Periodical For The Languages, Literature and History of Turkish or Turkic, 8 / 4, 427 - 440.

DAŞDEMIR, Ö. (2012). Halk Hikâyesi Olarak Yusuf ile Züleyha. Erzurum: Fenomen Yayıncilik.

DEMIR, N. ve ERDEM, M. D. (2006). Türk Kültüründe Destan ve Battal Gazi Destanı. Turkish Studies-International Periodical For The Languages, Literature and History of Turkish or Turkic, 1, 97 - 139. 
DUYMAZ, A. (2001). Kerem İle Aslı Hikâyesi Üzerinde Mukayeseli Bir Araştırma. Ankara: Kültür Bakanlığı Yayınları.

EFE, A. (2007). Peygamberler Tarihi Ansiklopedisi. Ankara: Akçağ Yayınları.

ELMALILI M. H. YAZIR (2011). Kur'an-I Kerim 'in Yüce Meali. İstanbul: Ravza Yayınları.

ERGIN, M. (1997). Dede Korkut Kitabı I. Giriş-Metin-Faksimile. Ankara: Türk Dil Kurumu Yayınlar1.

KÖKSAL, H. (1984). Battalnâmelerde Tip ve Motif Yapısı. Ankara: Kültür ve Turizm Bakanlığ Millî Folklor Araştırma Dairesi Yayınları.

KÖKSAL, H. (2007). Battal Gazi Destanı. Ankara: Akçă̆ Yayınları.

KÖPRÜLÜ, M. F. (2004). Türk Edebiyatı Tarihi. Ankara: Akçağ Yayınları.

KÜLEKÇİ, N. (1999). Mesnevi Edebiyatı Antolojisi C. 2. Erzurum: Aktif Yayınevi.

ONAY, A. T. (1996). Eski Türk Edebiyatında Mazmunlar. İstanbul: Milli Eğitim Bakanlığı Yayınları.

ÖZARSLAN, M. (2006). Ferhat İle Şirin Mukayeseli Bir Araşttrma. İstanbul: Doğu Kütüphanesi Yayıncılık.

PAKALIN, M. Z. (1993). Osmanlı Tarih Deyimleri ve Terimleri Sözlüğü III. İstanbul: Milli Eğitim Bakanlığı Yayınları.

PALA, İ. (1995). Ansiklopedik Divan Şiiri Sözlüğü. Ankara: Akçağ Yayınları.

PALA, İ. (2003). Tavan Arası. İstanbul: LM Yayınları.

SURUÇ, S. (2006a). Allah'ın Elçisi Hz. Muhammed'in Hayatı 1-Mekke Devri. İstanbul: Timaş Yayınları.

SURUÇ, S. (2006b). Allah'ın Elçisi Hz. Muhammed'in Hayatı 2-Medine Devri. İstanbul: Timaş Yayınları. 